\title{
Comparative assessment of water quality at Durban beaches according to local and international guidelines
}

\author{
David Mardon and Derek Stretch* \\ Centre for Research in Environmental, Coastal \& Hydrological Engineering (CRECHE), School of Civil Engineering, \\ University of Natal, Durban 4041, South Africa
}

\begin{abstract}
The pathogenic pollution of Durban's beaches is reviewed on the basis of local and international guidelines by analysing concentrations of indicator micro-organisms ( $E$. coli and enterococci). The average water quality is generally acceptable according to South African guidelines, but assessments based on international guidelines indicate poor water quality at many beaches during some seasons (especially summer). The reason for this inconsistency is the absence of any enterococcus criteria in the SA guidelines, which was found to be particularly significant when the pollution loadings are relatively low. This result confirms epidemiological studies that have shown enterococcus to be a more sensitive indicator of pathogenic pollution in marine environments. South African guidelines should therefore be updated to incorporate enterococcus as the preferred indicator for marine waters.
\end{abstract}

Keywords: pathogenic pollution, water quality guidelines, indicator micro-organisms, E-coli, enterococci

\section{Introduction}

Durban is situated on the East Coast of South Africa where the subtropical climate makes the beaches a popular destination for marine recreational activities. Pathogenic pollution of beach waters can have serious social and financial implications by having negative impacts on public health and the tourism industry. Pathogens are any organisms, micro-organisms, or virus that can cause disease.

The dominant source of pathogenic pollution is human faecal discharges that enter the water body through stormwater or river discharges.

The direct identification and enumeration of pathogens in water bodies can be difficult and costly. Therefore indicator microorganisms are used to identify and quantify the presence of pathogens. The two indicators most widely used are Escherichia coli (E. coli) and enterococcus.

Epidemiological studies have shown that enterococcus is a better indicator of pathogenic pollution in the case of marine environments (Fattal et al., 1983; Prüss, 1998).

The research reported here was part of a broader study (Mardon, 2003) into the fate and transport of pollution in the near-shore region of the Durban bight where the main objective was to develop a model to predict daily pathogen levels at the beaches for management purposes. In this paper we focus on results from one aspect of that study, namely a statistical analysis of the pathogenic pollution levels at Durban's beaches and a comparative evaluation of the water quality according to pertinent South African (SA) and international guidelines. The aims of this paper are therefore to:

- Report the outcome of beach water quality assessments according to local and international guidelines, identifying any inconsistencies.

* To whom all correspondence should be addressed.

פ⿴囗十灬⿴囗十 +27 31 260-1064; fax:+27 31260 -1411; e-mail: stretchd@ukzn.ac.za Received 23 August 2003; accepted in revised form 7 April 2004.

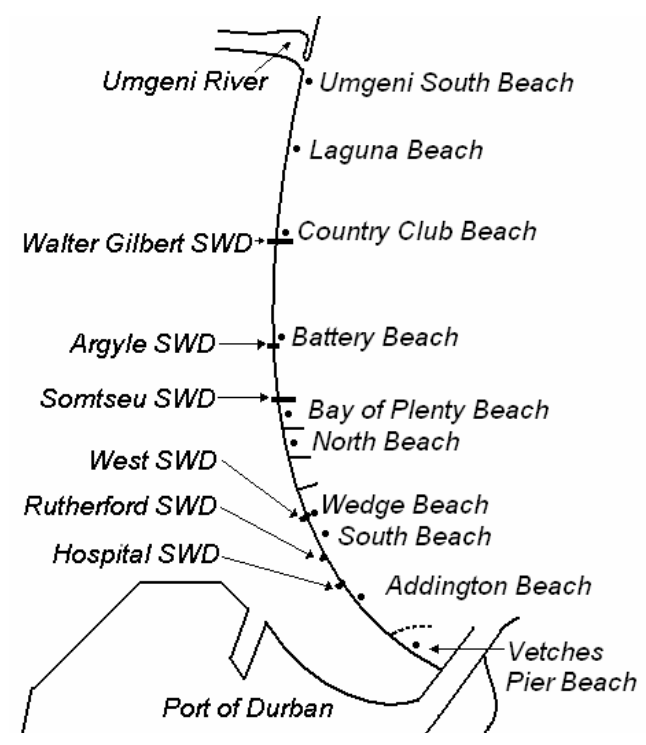

Figure 1

The Durban Bight case study area showing the location of the sampled beaches and stormwater drains

- Make recommendations on improving current SA marine water quality guidelines based on the comparison with international standards.

\section{Durban's beaches and pollution sources}

\section{Water quality monitoring}

A local government department, eThekwini Municipality Water and Sanitation (EMWS), is responsible for monitoring water quality in the Durban area. EMWS sample the water from beaches, stormwater drains, and rivers in the Durban Bight between the port 
entrance in the south and the Umgeni River mouth in the north (see Fig. 1). The samples are analysed using standard methods (Standard Methods, 1992) that enumerate the presence of indicator micro-organisms with the counts reported as colony forming units per $100 \mathrm{~m} \ell$ of water $(\mathrm{CFU} / 100 \mathrm{~m} \ell)$.

The beaches from Addington to Laguna Beach (Fig. 1) are designated bathing beaches. Vetches Beach is utilised for other full contact recreational activities (e.g. diving, boating). Umgeni South Beach is used primarily for non-contact activities (e.g. fishing) while Laguna Beach is used for jet-ski and kite-boarding activities. The beaches from Addington to Battery are of special concern since they are used extensively for public bathing and support the hotels and tourist activities that are situated in the area.

Beach water sampling is currently performed at fortnightly intervals. E. coli data from January 1995 to August 2002 were analysed in this study. Testing for enterococcus started in March 1999. The enterococcus data from March 1999 to August 2002 were therefore analysed for comparison with the E. coli data. Wedge Beach is an exception in that it has only been sampled from June 2000 (both E. coli and enterococcus).

\section{Near-shore pollution sources}

The recent study by Mardon (2003) has shown that discharges from the Umgeni River and six stormwater drains (SWD) are the main sources of pathogenic pollution to the beaches (see Fig. 1). The catchment areas of the six stormwater drains are given in Table 1.

\begin{tabular}{|l|c|}
\hline \multicolumn{2}{|c|}{ TABLE 1 } \\
Stormwater drain \\
catchment areas
\end{tabular}

Discharges from the drains and the Umgeni River are sampled and analysed by EMWS at monthly intervals. Only E. coli concentrations are enumerated. Statistical analysis of recent data from June 2000 to August 2002 was carried out as part of the present study. Median $\left(50^{\text {th }}\right.$ percentile $)$ and $95^{\text {th }}$ percentile E. coli concentrations in the stormwater discharges and Umgeni River are shown in Tables 2 and 3 respectively. Annual statistics are based on the full data set while seasonal values are calculated by grouping the data according to season: Summer (December to February), autumn (March to May), winter (June to August), and spring (September to November).

The statistics in Tables 2 and 3 indicate that $E$. coli concentrations in the stormwater drains are on average higher, and have greater variability, during spring and summer months. Durban has a summer rainfall climate, so the pollution loads in the stormwater are expected to be somewhat higher during spring and summer. Median E. coli concentrations in the Umgeni River are more consistent over the seasons but $95^{\text {th }}$ percentile values are highest in autumn.

Argyle SWD has the highest E. coli concentrations both annually and seasonally. It also has the second largest catchment area (Table 1) which combined with high average E. coli concen-
TABLE 2

Median $\left(50^{\text {th }}\right.$ percentile) E. coli concentrations of stormwater drains and rivers

\begin{tabular}{|l|c|c|c|c|c|}
\hline & Annual & Summer & Autumn & Winter & Spring \\
\hline Hospital & 1750 & 260 & 750 & 2950 & 5250 \\
Rutherford & 3000 & 11000 & 5500 & 0 & 3250 \\
West & 1000 & 1500 & 330 & 950 & 1000 \\
Somtseu & 3500 & 4400 & 2000 & 2000 & 2250 \\
Argyle & 23000 & 36000 & 30000 & 4650 & 80000 \\
Walter Gilbert & 5500 & 11600 & 5750 & 3900 & 5900 \\
Umgeni River & 2300 & 2500 & 2150 & 3000 & 2000 \\
\hline
\end{tabular}

TABLE 3

$95^{\text {th }}$ Percentile E. coli concentrations of stormwater drains and rivers

\begin{tabular}{|l|c|c|c|c|c|}
\hline & Annual & Summer & Autumn & Winter & Spring \\
\hline Hospital & 174500 & 41600 & 24000 & 159500 & 370000 \\
Rutherford & 270000 & 355000 & 50000 & 112500 & 272500 \\
West & 33600 & 72400 & 28750 & 58495 & 13250 \\
Somtseu & 78000 & 120000 & 26400 & 67250 & 81000 \\
Argyle & 821250 & 826500 & 400000 & 347000 & 989000 \\
Walter Gilbert & 47000 & 47150 & 26450 & 11700 & 144450 \\
Umgeni River & 42000 & 41200 & 82000 & 23000 & 28000 \\
\hline
\end{tabular}

trations, make it the most significant source of pathogenic pollution amongst the stormwater drains.

Umgeni River has lower E. coli concentrations than the stormwater drains but a much larger average flow rate. It is therefore potentially the highest overall source of pathogenic pollution for the near-shore region.

\section{Review of water quality guidelines}

Our analysis of beach water quality along the Durban Bight utilised three water quality guidelines:

- South African Water Quality Guidelines for Coastal Marine Waters (DWAF, 1995)

- Ambient Water Quality Guidelines for Bacteria (US EPA, 1986)

- 2002 EU Bathing Water Quality Directive (COM, 2002)

Each of these guidelines is briefly summarised in the sections below. The scientific information underpinning the specification of specific pollution limits (e.g. the estimation of health risks from epidemiological studies) can be found in the guideline documents themselves or in references cited therein. For the purposes of the present discussion it is assumed that any exceedance of a specified guideline limit would expose users to an unacceptable health risk, according to the guideline concerned. The precise definition of "unacceptable health risk" is beyond the scope of our research. However, comparing evaluations based on each of the three guidelines does at least provide a consistency check.

\section{South African marine recreational guidelines}

South African water quality (SA WQ) guidelines consider only E. coli as an indicator of pathogenic pollution (DWAF, 1995). For 
full and intermediate contact recreational waters, the following two limits for enumerated $E$. coli are specified:

- Less than $20 \%$ of samples to exceed $100 \mathrm{CFU} / 100 \mathrm{~m} \ell$

- Less than $5 \%$ of samples to exceed $2000 \mathrm{CFU} / 100 \mathrm{m \ell}$

The guidelines do not set limits for enterococcus concentrations, nor do they specify a sampling frequency.

\section{US EPA water quality guidelines}

The United States Environmental Protection Agency (US EPA) guideline for recreational waters (US EPA, 1986) stipulates two criteria for both fresh and marine (full body contact) recreational waters.

The first criterion is that the geometric mean (GM) of a "statistically sufficient" number of samples (defined as usually more than 5 samples equally spaced over a $30 \mathrm{~d}$ period) should not exceed a limiting value set for the specific indicator micro-organism. The second criterion is a single sample limit (SSL) which should not be exceeded by any sample. The SSL is set by Eq. (1) using the GM limit and a factored log-standard deviation value that depends on the type of bathing use.

$$
S S L=10^{\left[\log \left(G M_{\text {Limit }}\right)+\text { factor } * \sigma_{\log }\right]}
$$

The log-standard deviation should be determined from a sampling record where possible, but default values of 0.4 for freshwater (E.coli and enterococcus) and 0.7 for marine water (enterococcus) are recommended where the sampling history is limited. The appropriate scaling factor in Eq. (1) is specified as a one-sided confidence limit (CL) with a probability value specific to the beach use, as follows:

- Designated bathing use: $75 \%$

- Moderate use for bathing: $82 \%$

- Light use for bathing: $90 \%$

- Infrequent use for bathing: $95 \%$

In the case of freshwater, the EPA specifies that the GM for E-coli should not exceed $126 \mathrm{CFU} / 100 \mathrm{~m} \ell$, and/or for enterococcus should not exceed $33 \mathrm{CFU} / 100 \mathrm{~m} \ell$. In the case of marine waters, the EPA give a GM limit of $35 \mathrm{CFU} / 100 \mathrm{~m} \ell$ for enterococcus but do not specify an $E$. coli limit since they no longer use it as an indicator for marine environments.

Prior to 1986 the EPA used a faecal coliform GM limit of 200 CFU/100 m $\ell$ with an upper single sample faecal coliform limit of $400 \mathrm{CFU} / 100 \mathrm{~m} \ell$.

\section{EU bathing water directive}

The EU guidelines (COM, 2002) specify two $95^{\text {th }}$ percentile limits for $E$. coli and enterococcus in bathing waters. They are referred to as "guide" and "obligatory" limits (see Table 4).

\begin{tabular}{|l|c|c|}
\hline \multicolumn{3}{|c|}{ TABLE 4 } \\
2002 EU bathing water quality criteria \\
\hline Parameters & $\begin{array}{c}\text { Excellent } \\
\text { quality (Guide) }\end{array}$ & $\begin{array}{c}\text { Good quality } \\
\text { (Obligatory) }\end{array}$ \\
\hline $\begin{array}{l}\text { Enterococcus }(\mathrm{CFU} / 100 \mathrm{~m} \ell) \\
\text { E.coli }(\mathrm{CFU} / 100 \mathrm{~m} \ell)\end{array}$ & 100 & 200 \\
& 250 & 500 \\
\hline
\end{tabular}

The EU guidelines require three previous calendar years of sampled data for E. coli and enterococcus. The $95^{\text {th }}$ percentile values are determined using a parametric approach. The logarithms of the data are taken, from which the mean $(\mu)$ and standard deviation $(\sigma)$ are estimated. The $95^{\text {th }}$ percentile $\left(V_{P 95}\right)$ values are then obtained from

$$
V_{P 95}=e^{\left(\mu+1.65^{*} \sigma\right)}
$$

The $95^{\text {th }}$ percentile values for $E$. coli and enterococcus are then used to classify the water quality as follows:

- If either are higher than their obligatory values then the bathing water is classified as "Poor"

- If both are equal to or less than the obligatory value then the bathing water is classified as "Good"

- If both are equal to or less than the guide value then the bathing water is classified as "Excellent".

The EU guideline procedure is based on the assumption that indicator concentrations are log-normally distributed. This assumption has been found to be a good approximation for Durban's beaches (Mardon, 2003).

The EU guidelines are consistent with the recently updated World Health Organisation guidelines (WHO, 2001).

\section{Analysis of Durban bathing beaches}

\section{SA Marine recreational guidelines}

\section{Analysis methods}

Both annual and seasonal (as defined above) exceedance statistics were estimated by the usual method of ranking the data and counting the values above specified limits. Only E. coli data were used in this case since the SA water quality guidelines are based solely on this indicator.

\section{Analysis results}

The annual exceedance percentages of the SA WQ guideline concentration levels are given in Tables 5 and 6.

The summer and autumn seasons usually have the greatest proportion of unacceptable water quality. It can be seen that all beaches from Vetches to Bay of Plenty satisfy both of the SA WQ guideline exceedance levels. The remaining beaches (Battery to Umgeni South) exceed the first guideline value annually and for most seasons, since more than $20 \%$ of the samples are greater than $100 \mathrm{CFU} / 100 \mathrm{~m} \ell$. Umgeni South exceeds the second guideline limit annually and for most seasons, spring being the exception. Battery Beach annually has less than $5 \%$ of samples greater than $2000 \mathrm{CFU} / 100 \mathrm{~m} \ell$; however, during summer and autumn this limit is exceeded.

Overall Battery Beach is the most problematic bathing beach since it fails both SA WQ criteria during the summer and autumn. North Beach, although not failing any of the exceedance criteria annually, exceeded the $100 \mathrm{CFU} / 100 \mathrm{~m} \ell$ guideline value in $18 \%$ of summer samples. This should be of concern as bathing beaches are used intensively during the summer holiday period. Bay of Plenty Beach is another beach where the percentage of samples greater than $100 \mathrm{CFU} / 100 \mathrm{~m} \ell$ are only marginally less than the SA WQ limit. 


\begin{tabular}{|c|c|c|c|c|c|}
\hline \multicolumn{6}{|c|}{$\begin{array}{c}\text { TABLE } 5 \\
\text { SA Marine WQ Guideline Criteria } 1 \text { (Max } 20 \% \text { of } \\
\text { samples greater than } 100 \mathrm{CFU} / 100 \mathrm{ml})\end{array}$} \\
\hline $\begin{array}{l}\text { Designated } \\
\text { bathing }\end{array}$ & Annual & Summer & Autumn & Winter & Spring \\
\hline Vetches Pier & $7 \%$ & $8 \%$ & $6 \%$ & $9 \%$ & $5 \%$ \\
\hline Addington & $6 \%$ & $11 \%$ & $2 \%$ & $6 \%$ & $7 \%$ \\
\hline South & $6 \%$ & $8 \%$ & $4 \%$ & $8 \%$ & $2 \%$ \\
\hline Wedge & $8 \%$ & $0 \%$ & $0 \%$ & $13 \%$ & $15 \%$ \\
\hline North & $8 \%$ & $18 \%$ & $4 \%$ & $8 \%$ & $2 \%$ \\
\hline Bay & $13 \%$ & $15 \%$ & $15 \%$ & $17 \%$ & $2 \%$ \\
\hline Battery & $34 \%$ & $28 \%$ & $41 \%$ & $40 \%$ & $27 \%$ \\
\hline Country Club & $20 \%$ & $26 \%$ & $22 \%$ & $17 \%$ & $16 \%$ \\
\hline Laguna & $28 \%$ & $47 \%$ & $24 \%$ & $22 \%$ & $18 \%$ \\
\hline Umgeni South & $48 \%$ & $72 \%$ & $48 \%$ & $38 \%$ & $40 \%$ \\
\hline
\end{tabular}

\begin{tabular}{|l|c|c|c|c|c|}
\hline \multicolumn{5}{|c|}{ TABLE 6 } \\
\hline \multicolumn{6}{|c|}{ SA Marine WQ Guideline Criteria 2 (Max 5\% of } \\
samples greater than 2000 CFU/100 m $\mathbf{~ ) ~}$ \\
\hline $\begin{array}{l}\text { Designated } \\
\text { bathing }\end{array}$ & Annual & Summer & Autumn & Winter & Spring \\
\hline Vetches Pier & $0 \%$ & $0 \%$ & $0 \%$ & $0 \%$ & $0 \%$ \\
Addington & $1 \%$ & $0 \%$ & $0 \%$ & $2 \%$ & $0 \%$ \\
South & $0 \%$ & $0 \%$ & $0 \%$ & $0 \%$ & $0 \%$ \\
Wedge & $0 \%$ & $0 \%$ & $0 \%$ & $0 \%$ & $0 \%$ \\
North & $0 \%$ & $0 \%$ & $0 \%$ & $0 \%$ & $0 \%$ \\
Bay & $0 \%$ & $0 \%$ & $0 \%$ & $0 \%$ & $0 \%$ \\
Battery & $3 \%$ & $\mathbf{5 \%}$ & $\mathbf{8 \%}$ & $0 \%$ & $0 \%$ \\
Country Club & $0 \%$ & $0 \%$ & $0 \%$ & $0 \%$ & $0 \%$ \\
Laguna & $1 \%$ & $0 \%$ & $0 \%$ & $2 \%$ & $0 \%$ \\
Umgeni South & $\mathbf{1 2 \%}$ & $\mathbf{2 1 \%}$ & $\mathbf{1 6 \%}$ & $\mathbf{1 1 \%}$ & $2 \%$ \\
\hline
\end{tabular}

\section{US EPA water quality guidelines}

\section{Analysis methods}

The GM criteria set by the US EPA guideline indicates that 5 samples per 30-day period are required. The fortnightly sampling of Durban's beaches is too infrequent to meet this requirement. However, the implementation guidance document (US EPA, 2000) states that the guideline should not be interpreted as specifying a minimum number of samples. Rather it is the GM of the samples collected, in conjunction with a single sample maximum, which determines compliance with the water quality criteria, regardless of the number collected. The GM was therefore calculated using 3 samples spanning an approximate $30 \mathrm{~d}$ period. The use of fewer samples does, however, imply a higher statistical uncertainty in the GM estimates.

Since the EPA does not specify E. coli GM limits for marine waters, it was decided to use their freshwater limits in order to check how the WQ assessment depended on the use of different indicator micro-organisms.

The application of the EPA SSL guideline requires the stipulation of a "use" category for the beaches. Beaches from Addington to Battery were assumed to be in the "designated bathing" category, while Vetches, Country Club and Laguna were assumed to be in the "moderate use for bathing" category. Umgeni South is not usually used for bathing but was assumed to fall in the "infrequent use for bathing" category in order to assess the risks associated with watersport activities at the beaches adjacent to the river mouth.

\section{Geometric mean analysis results}

The results of the beach WQ analysis with respect to the EPA GM guideline limits for freshwater $E$. coli and marine enterococcus are shown in Table 7.

\begin{tabular}{|c|c|c|c|}
\hline \multicolumn{4}{|c|}{$\begin{array}{c}\text { TABLE } 7 \\
\text { Exceedance of the US EPA geometric mean } \\
\text { guideline limits }\end{array}$} \\
\hline Indicator & \multicolumn{2}{|c|}{ Escherichia coli } & Entero- \\
\hline Start Date & Jan-1995 & Mar-1999 & Mar-1999 \\
\hline End Date & Aug-2002 & Aug-2002 & Aug-2002 \\
\hline Vetches Pier & $0 \%$ & $0 \%$ & $7 \%$ \\
\hline Addington & $0 \%$ & $0 \%$ & $5 \%$ \\
\hline South & $0 \%$ & $0 \%$ & $6 \%$ \\
\hline Wedge & $0 \%$ & $0 \%$ & $10 \%$ \\
\hline North & $0 \%$ & $0 \%$ & $4 \%$ \\
\hline Bay of Plenty & $4 \%$ & $5 \%$ & $6 \%$ \\
\hline Battery & $29 \%$ & $44 \%$ & $34 \%$ \\
\hline Country Club & $10 \%$ & $11 \%$ & $20 \%$ \\
\hline Laguna & $18 \%$ & $25 \%$ & $21 \%$ \\
\hline Umgeni South & $51 \%$ & $63 \%$ & $63 \%$ \\
\hline
\end{tabular}

Battery beach is again seen to be the most polluted bathing beach, with the EPA GM limits exceeded for approximately one third of the time.

An interesting result concerns the difference between the results based on $E$. coli vs. enterococci for the beaches from Vetches Pier to North. The E. coli GM limit is never exceeded at those locations, whilst the enterococcus GM limit is exceeded for between $3 \%$ and $10 \%$ of the time. For the more polluted beaches from Battery to Umgeni, the differences are small. These results support the conclusion (e.g. Prüss, 1998) that enterococcus is a more sensitive indicator of pathogenic pollution for marine environments, especially at low concentration levels.

Note that $E$. coli exceedances for the period 1995 to 2002 are generally lower than for 1999 to 2002 . Rather than an increase in the pollution of the beaches, this seems to reflect improvements to the testing methods that were introduced after 1999 (Jackson et al., 2002).

\section{Single sample limit analysis results}

Exceedance percentages for the enterococcus SSL for each "use category" are shown in Table 8 . Summer has the largest percentage of enterococci SSL exceedances for most beaches. Battery Beach is an exception where the autumn season experiences the largest SSL exceedance. Battery Beach also has the largest SSL exceedances of all the bathing beaches (32\% in autumn and 27\% in summer). Although North Beach exceeded the SSL only $6 \%$ annually, all these exceedances occurred during summer (27\%). Therefore, according to this criterion, North Beach is as polluted as Battery Beach during the summer season.

The percentage of beach observations where both the GM and SSL guidance values for enterococcus were exceeded is shown in Table 9. 


\begin{tabular}{|l|c|c|c|c|c|}
\hline \multicolumn{5}{|c|}{ TABLE 8 } \\
\hline \multicolumn{5}{|c|}{ Exceedance of the US EPA SSL for enterococcus } \\
\hline $\begin{array}{l}\text { Designated } \\
\text { bathing }\end{array}$ & Annual & Summer & Autumn & Winter & Spring \\
\hline $\begin{array}{l}\text { Addington } \\
\text { South }\end{array}$ & $4 \%$ & $7 \%$ & $0 \%$ & $5 \%$ & $6 \%$ \\
Wedge & $7 \%$ & $7 \%$ & $10 \%$ & $5 \%$ & $6 \%$ \\
North & $4 \%$ & $0 \%$ & $0 \%$ & $10 \%$ & $8 \%$ \\
Bay & $6 \%$ & $27 \%$ & $0 \%$ & $0 \%$ & $0 \%$ \\
Battery & $4 \%$ & $14 \%$ & $5 \%$ & $0 \%$ & $0 \%$ \\
\hline Moderate & $23 \%$ & $27 \%$ & $32 \%$ & $20 \%$ & $11 \%$ \\
use & Annual & Summer & Autumn & Winter & Spring \\
\hline Vetches Pier & $7 \%$ & $7 \%$ & $9 \%$ & $0 \%$ & $13 \%$ \\
Country Club & $13 \%$ & $20 \%$ & $14 \%$ & $5 \%$ & $13 \%$ \\
Laguna & $11 \%$ & $29 \%$ & $5 \%$ & $11 \%$ & $6 \%$ \\
\hline Infrequent & Annual & Summer & Autumn & Winter & Spring \\
\hline use & & & & & \\
\hline Umgeni South & $25 \%$ & $53 \%$ & $29 \%$ & $16 \%$ & $6 \%$ \\
\hline
\end{tabular}

\begin{tabular}{|c|c|c|c|c|c|}
\hline \multicolumn{6}{|c|}{$\begin{array}{c}\text { TABLE } 9 \\
\begin{array}{c}\text { US EPA beach use failure (US EPA GM and SSL } \\
\text { criteria combined) }\end{array}\end{array}$} \\
\hline $\begin{array}{l}\text { Designated } \\
\text { bathing }\end{array}$ & Annual & Summer & Autumn & Winter & Spring \\
\hline Addington & $1 \%$ & $0 \%$ & $0 \%$ & $0 \%$ & $6 \%$ \\
\hline South & $3 \%$ & $7 \%$ & $5 \%$ & $0 \%$ & $0 \%$ \\
\hline Wedge & $2 \%$ & $0 \%$ & $0 \%$ & $0 \%$ & $8 \%$ \\
\hline North & $3 \%$ & $13 \%$ & $0 \%$ & $0 \%$ & $0 \%$ \\
\hline Bay & $1 \%$ & $7 \%$ & $0 \%$ & $0 \%$ & $0 \%$ \\
\hline Battery & $16 \%$ & $13 \%$ & $25 \%$ & $10 \%$ & $11 \%$ \\
\hline $\begin{array}{l}\text { Moderate } \\
\text { use }\end{array}$ & Annual & Summer & Autumn & Winter & Spring \\
\hline Vetches Pier & $1 \%$ & $0 \%$ & $0 \%$ & $0 \%$ & $6 \%$ \\
\hline Country Club & $5 \%$ & $13 \%$ & $4 \%$ & $5 \%$ & $0 \%$ \\
\hline Laguna & $8 \%$ & $27 \%$ & $9 \%$ & $0 \%$ & $0 \%$ \\
\hline $\begin{array}{l}\text { Infrequent } \\
\text { use }\end{array}$ & Annual & Summer & Autumn & Winter & Spring \\
\hline Umgeni South & $23 \%$ & $47 \%$ & $24 \%$ & $17 \%$ & $6 \%$ \\
\hline
\end{tabular}

Battery Beach is again the worst affected designated bathing beach, with the enterococcus levels annually exceeding both GM and SSL values in $16 \%$ of beach samples. All other designated bathing beaches have typically between $1 \%$ and $3 \%$ annual exceedance of the US EPA WQ criteria. There is a marked difference in the seasonal analysis of the beaches, with summer, and to a lesser degree spring and autumn, having the highest percentage of failures. A significant observation is that during summer, North Beach has the same exceedances as Battery Beach $(13 \%)$.

\section{EU bathing water directive}

\section{Analysis methods}

The 2002 EU bathing water directive states that a 3-year record of sampled indicator concentrations should be utilized for determining the quality of beach bathing waters. The period from November 1999 to August 2002 was analysed.

A problem arose using the parametric approach for estimating the $95^{\text {th }}$ percentile value because a significant proportion of the beach samples were measured as having zero $E$. coli or enterococcus counts. The testing method used by EMWS is designed to detect high values that exceed water quality standards, while lower indicator concentrations are not accurately measured. Enterococcus counts were most affected, with beaches from Vetches to Bay of Plenty having $30 \%$ to $70 \%$ of their indictor concentrations recorded as zero. The World Health Organisation guideline (WHO, 2001) on which the 2002 EU guidelines are based, states that zero readings should be replaced by a value representing the lowest detectable value (in this case 1 to $10 \mathrm{CFU} / 100 \mathrm{~m} \ell$ ). However, a large proportion of zero concentrations can make the analysis sensitive to the selected minimum value. Another method suggested by WHO (2001) is to fit a probability density function (PDF) based on the observations and then to use the properties of this PDF to estimate the $95^{\text {th }}$ percentile. The latter approach was used for this study. The fitted PDF method was found to agree with the parametric approach if values of between 1 and $5 \mathrm{CFU} / 100 \mathrm{~m} \ell$ were used to replace zero counts.

\section{Analysis results}

The $95^{\text {th }}$ percentile values for $E$. coli and enterococcus were categorised according to the 2002 EU WQ criteria limits (Table 4), a summery of which is shown in Table 10. The pathogenic indicators, E. coli and enterococcus, are labelled as EC and EN respectively. The categorised $95^{\text {th }}$ percentile values are represented as follows:

- No entry when less than the guide value

- A "G" entry when higher than the guide but lower then the obligatory values

- An "F" entry when higher than the obligatory value.

The number preceding the " $F$ " entry indicates the magnitude of the calculated $95^{\text {th }}$ percentile values as a multiple of the obligatory limit. For example " $4 \mathrm{~F}$ " for $E$. coli means that the $95^{\text {th }}$ percentile was approximately 4 times higher than the limit (i.e. $2000 \mathrm{CFU} /$ $100 \mathrm{~m} \ell$ ).

\begin{tabular}{|c|c|c|c|c|c|}
\hline \multicolumn{6}{|c|}{$\begin{array}{c}\text { TABLE } 10 \\
\text { Categorisation summary of } E \text {. coli and enterococcus } \\
95^{\text {th }} \text { percentile values }\end{array}$} \\
\hline Season & Annual & Summer & Autumn & Winter & Spring \\
\hline Indicat & EC EN & EC $\quad$ EN & EC EN & EC EN & EC EN \\
\hline Vetches & $-F$ & & & & $-2 \mathrm{~F}$ \\
\hline Adding & $-\quad G$ & $-G$ & - & G & $\mathrm{F}$ \\
\hline South & & & & $\mathrm{G}$ & \\
\hline Weds & & - & - & G & \\
\hline North & & $\mathrm{F}$ & - & - & \\
\hline Bay of Plenty & & & $-G$ & - & \\
\hline Battery & $5 \mathrm{~F} \quad 3 \mathrm{~F}$ & $10 \mathrm{~F} \quad 4 \mathrm{~F}$ & $10 \mathrm{~F} \quad 6 \mathrm{~F}$ & $\mathrm{~F}$ & $2 \mathrm{~F} \quad 6 \mathrm{~F}$ \\
\hline Country Club & & $\mathrm{F} \quad 4 \mathrm{~F}$ & & $\mathrm{G} \quad 2 \mathrm{~F}$ & G $\quad \mathrm{G}$ \\
\hline Laguna & $2 \mathrm{~F} \quad 2 \mathrm{~F}$ & $\mathrm{~F} \quad 10 \mathrm{~F}$ & $\mathrm{~F} \quad 2 \mathrm{~F}$ & $2 \mathrm{~F} \quad 2 \mathrm{~F}$ & $3 F \quad G$ \\
\hline Umgeni South & $11 \mathrm{~F} 8 \mathrm{~F}$ & $\mathrm{~F} \quad 19 \mathrm{~F}$ & $16 \mathrm{~F} \quad 6 \mathrm{~F}$ & $6 \mathrm{~F} \quad 6 \mathrm{~F}$ & $3 \mathrm{~F} \quad 4 \mathrm{~F}$ \\
\hline
\end{tabular}


TABLE 11

EU bathing water quality assessment (1999 to 2002)

\begin{tabular}{|l|c|c|c|c|c|}
\hline Beach & Annual & Summer & Autumn & Winter & Spring \\
\hline Vetches & Poor & Poor & Good & Excellent & Poor \\
Addington & Good & Good & Excellent & Poor & Poor \\
South & Good & Good & Good & Good & Good \\
Wedge & Good & Excellent & Excellent & Good & Good \\
North & Excellent & Poor & Excellent & Excellent & Excellent \\
Bay of Plenty & Good & Poor & Good & Excellent & Excellent \\
Battery & Poor & Poor & Poor & Poor & Poor \\
Country Club & Poor & Poor & Poor & Poor & Good \\
Laguna & Poor & Poor & Poor & Poor & Poor \\
Umgeni S & Poor & Poor & Poor & Poor & Poor \\
\hline
\end{tabular}

TABLE 12

Summary of WQ guideline assessments

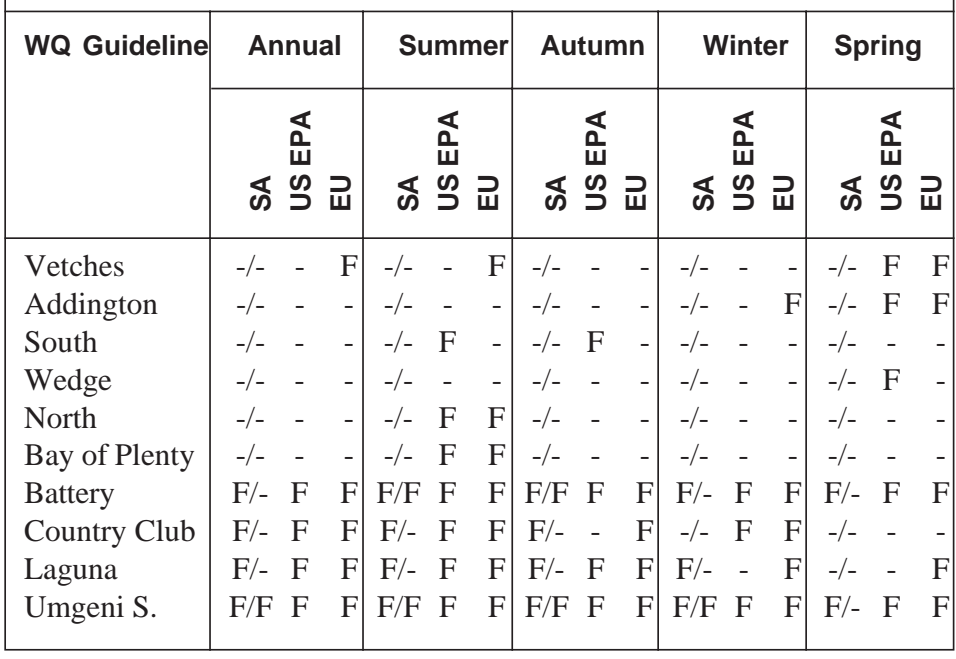

Table 10 illustrates the clear distinction in water quality between the heavily polluted beaches (Battery to Umgeni South) and the less polluted beaches (Vetches to Bay of Plenty). It is important to note that for the less polluted beaches, enterococcus is typically the defining water quality indicator. In most cases the E. coli $95^{\text {th }}$ percentile values are lower than the guide value $(250 \mathrm{CFU} / 100 \mathrm{~m} \ell)$ while enterococcus typically either exceeds the guide (100 CFU/ $100 \mathrm{~m} \ell$ ) or obligatory (200 CFU/100 m $/$ ) limits. Country Club Beach, although exceeding both obligatory indicator limits, is noticeably less polluted than the adjacent beaches (Battery and Laguna Beach).

An overall classification of the beaches according to EU guidelines is given in Table 11. North beach is the only beach to achieve an overall "Excellent" rating based on annual statistics, while only the beaches from Addington to Bay of Plenty have acceptable pathogenic pollution levels according to EU guidelines. Using seasonal statistics the assessment varies substantially, with Vetches (spring \& summer), Addington (winter \& spring), North (summer) and Bay of Plenty Beach (summer) having "poor" bathing water quality ratings. The beaches from Battery to Umgeni South have "poor" bathing water quality ratings both annually and seasonally, with the exception of Country Club during spring.

It is noteworthy that during summer, which is the most active bathing period, four of the seven designated bathing beaches have a "poor" water quality ratings according to the EU guideline.

\section{Discussion and conclusions}

A summary of the bathing water quality assessments given by the different guidelines is presented in Table 12. An "F" entry indicates the failure of the specific guideline criteria, while "_." indicates acceptable pathogenic pollution levels. The SA guidelines are presented as "Criteria 1/Criteria 2 "from Table 5 and Table 6 respectively. The US EPA results are taken from Table 9, where failure is defined as combined exceedances of both GM and SSL criteria for $5 \%$ or more of samples. The EU assessment is from Table 11 and failure is defined as a "Poor" EU WQ rating.

The main findings may be summarised as follows:

- All beaches from (and including) Battery Beach northwards have water quality unacceptable for bathing according to all three guidelines.

- On an annual or seasonal basis, all beaches south of Battery have acceptable water quality according to SA guidelines, with no failures of either criteria.

- On an annual basis, Vetches Beach was found to fail the EU guideline only.

- On a seasonal basis, the situation is more complex. Both EU and EPA guidelines are exceeded at North Beach and Bay of Plenty during summer. Vetches and Addington Beaches also failed both international guidelines during spring. South Beach fails EPA guidelines (but not EU) during spring and autumn, while Wedge Beach fails during spring.

Therefore, while on the basis of annual statistics the water quality of all except the beaches from Battery Beach northwards are acceptable, the seasonal water quality for 8 of the 10 beaches is currently poor according to international guidelines. The SA marine water quality guidelines are inconsistent with the two international guidelines because of the absence of enterococcus criteria in the SA limits, which plays a particularly significant role where pollution loadings are low. Based on these results it is recommended that SA marine water quality guidelines be updated to include enterococcus criteria. As already noted, epidemiological studies have shown enterococcus to be a more reliable indicator of pathogenic pollution in marine waters (Fattal et al., 1983; Prüss, 1998).

A detailed investigation into specific causes of the pathogenic pollution at Durban's beaches was beyond the scope of this study. We speculate that informal settlements and/or trading activities in the stormwater drain catchments could be important factors. Battery Beach has a particularly serious water quality problem. Specific causes for this problem have been identified by EMWS (Siobhan Jackson, 2002) including leakages from sewerage systems into the stormwater system. The problem at Battery Beach appears to have a knock-on effect at adjacent beaches (e.g. North and Bay of Plenty). Mardon (2003) used a model to simulate the water quality of the beaches and estimated that an $80 \%$ reduction in the median pollution levels of Argyle SWD is required in order to improve the bathing water quality of Battery Beach to acceptable levels. Adjacent beaches (e.g. North and Bay of Plenty) would also benefit from this reduced pollution.

The poor bathing water quality at Umgeni South and Laguna is due to the pollution of the Umgeni River. The size of the river catchment and more diffuse nature of the pollution sources will make this problem more difficult to address and will require an integrated catchment management strategy. 


\section{Acknowledgements}

The authors are grateful to EMWS, particularly to Siobhan Jackson, for providing the water quality data for this study. The research was made possible by a grant from the Innovation Fund, administered by the Department of Arts, Culture, Science \& Technology, and forms part of the SA-ISIS project (see isis-cwqm.nu.ac.za).

\section{References}

COM (2002) Proposal for a Directive of the European Parliament and of the Council Concerning the Quality of Bathing Water. Commission of the European Communities, 2002/0254 (COD), Brussels, 24 November .

DWAF (1995) South African Water Quality Guidelines for Coastal Marine Waters. Volume 2: Recreational Use ( $1^{\text {st }} \mathrm{edn}$.). Department of Water Affairs and Forestry.

FATTAL B, VASL RJ, KATZENELSON E and SHUVAL HI (1983) Survival of bacterial indicator organism and enteric viruses in Mediterranean coastal waters off Tel-Aviv. Water Res. 17397.

JACKSON S (2002) Personal communication. eThekwini Municipality Water \& Sanitation, Microbiology Lab, Prior Rd, Durban, 4000.
JACKSON SAF, BAILEY I, BRITZ R, DE WET C, FORTUNE A, JOHNSTON-ROBERTSON AJ, NAIDOO KM and SUNDRAM A (2002) Report on the South African colilert ${ }^{\mathrm{tm}}$ ring trial. Proc WISA 2002 Conference, ICC Durban, 19-23 May.

MARDON DW (2003) Coastal Water Quality. M.Sc. Dissertation, University of Natal.

PRÜSS A (1998) A review of epidemiological studies from exposure to recreational water. Int. J. Epidemiol. 27 1-9.

STANDARD METHODS (1992) Standard Methods for the Examination of Water and Waste Waters (18 ${ }^{\text {th }}$ edn.). Clesceri LS, Greenberg AE \& Strussell RR (eds.) American Public Health Association.

US EPA (1976) Quality Criteria for Water. US Environmental Protection Agency, Washington DC.

US EPA (1986) Ambient Water Quality Criteria for Bacteria. US Environmental Protection Agency, Washington DC.

US EPA (2000) Implementation Guidance for Ambient Water Quality Criteria for Bacteria - 1986 (DRAFT). EPA-823-D-00-001. US Environmental Protection Agency, Washington DC. January.

WHO (2001) Bathing Water Quality and Human Health: Faecal Pollution. World Health Organisation, Report WHO/SDE/WSH/01.2. Vol 1 Ch. 4. Farnham, UK, April. 
